\title{
Comments on 'Trade policies in the U.S. automobile industry', by Penny Koujianou Goldberg
}

\author{
James A. Levinsohn \\ University of Michigan, National Bureau of Economic Research, Department of Economics, \\ Ann Arbor, MI 48109, USA
}

This is a paper on an important and timely topic and it represents a substantial improvement over much of the existing literature on the effects of trade policy in the U.S. automobile market. In particular, the use of consumer level data provided by the Consumer Expenditure Survey (CES) is a clever and useful approach to a problem frequently plagued by too little data. It is apparent that a great deal of time and effort have gone into this project.

When I first discussed this paper, I noted that I was troubled by four issues. These were the estimation of demand elasticities, consumer welfare, the treatment of direct foreign investment by Japanese firms, and the modelling of the North American Free Trade Agreement (NAFTA). I am still concerned by these issues, and I will discuss them in turn.

\section{Estimation of demand elasticities}

The demand elasticities are key to almost all the results in the paper. They drive the price-marginal cost markups which lead to profits and they determine consumers' substitution patterns in response to trade policies. While the methods used in this paper are careful and sophisticated, I think there is one potentially important problem with them.

I am grateful to Prof. Steve Berry, Yale University, and Prof. John Jackson, University of Michigan Law School, for helpful discussions. 
I believe the elasticities estimated are biased and that the true elasticities are more elastic than those used in the analysis. If I am correct, true markups (and hence the profits to be shifted by trade policy), are lower than those reported in the paper. In the discrete choice literature, a consumer obtains utility based on a car's characteristics, the consumer's tastes, and the car's price. The econometrician does not observe all the car's characteristics, for example 'quality', even though the consumer does observe these characteristics. If these unobserved characteristics are correlated with price, as we would expect them to be since higher quality cars tend to cost more, estimated elasticities are biased toward zero. Using consumer-level data as in this paper does not solve this problem unless the consumers' perceptions of how the unobserved characteristics affect price are independently and identically distributed across consumers. For example, if one consumer views a Mercedes or Lexus as having especially high quality, but the next consumer is just as likely to view it as having, say, very low quality, there is no problem. In the automobile market, though, this is unlikely. Work by Berry (1993) shows how to address this problem in a discrete choice framework, and his results show that the bias may be important. In Goldberg (1992), there is a discussion of using fixed effects to address this problem, but it is not clear whether the fixed effect is by model/year, by model, or by group of models. The first would be preferable, but with about 4500 households interviewed, about 450 are expected to purchase cars. With, as the author states, about 220 models per year, it seems unlikely that the author used a fixed effect for each model/year. The bottom line here is that the elasticities are probably significantly biased.

\section{Consumer welfare}

The author is admirably forthright about not worrying about consumers in this paper. I would like to go on the record as saying we ought to be worried, and the methodology used in this paper gives special cause for concern. We ought to be worried for the obvious reason: Consumers are usually the losers from an activist trade policy and research which concentrates on the profit side of the welfare equation only present one side, albeit an important side, of the story. The reason to be especially concerned in this paper is that I do not think that one can ever recover a utility based measure of consumer welfare from the methodology employed in this paper. The level of analysis and data in this paper is the consumer. Presumably, then, there is a distribution of tastes which, when confronted with the existing choice set of cars, gives rise to observed purchases. If one could back out this distribution of tastes, one would be in good shape to evaluate how utility changes with price changes. This would be an important (I would argue crucial) piece of 
evidence when considering the effects of a trade policy. The potential problem here is that due to the sequential nature of the demand side of the model, I do not see how one could ever recover the underlying utility function, and this is a significant drawback.

\section{Direct foreign investment}

The treatment of direct foreign investment by Japanese firms is a potential problem here. Some firms were quite constrained by the quota while others were not. Those that were most constrained were the first to invest. Honda, for example, opened its Marysville plant in 1982, the first full year of the Voluntary Export Restraint (VER). In the paper, it is suggested that assuming transplant output was subject to the quota will overstate the effect of protection. I agree. It is then suggested that this effect was small through 1986, and here I disagree. By 1986, Honda was producing about a quarter million cars in Ohio and Nissan another 65,000 in Tennessee. For a quota set somewhere around 1.68 to 1.85 million, 0.3 million cars, on the margin can be quite important. The bottom line here is that treating dfi output at imports

Table 1

The effect of the 1981-1984 VER on automobile prices (1971-1990 data)

\begin{tabular}{lcl}
\hline Dependent variable is $\ln$ (price) & & $\begin{array}{l}\text { Standard } \\
\text { error }\end{array}$ \\
\hline Variable & $\begin{array}{l}\text { Parameter } \\
\text { estimater }\end{array}$ & 0.035 \\
constant & 1.990 & 0.025 \\
In $(h p / w t)$ & 0.638 & 0.015 \\
air & 0.489 & 0.042 \\
ln(space) & 1.387 & 0.001 \\
trend & 0.025 & 0.041 \\
japan & 0.422 & 0.003 \\
jtrend & -0.021 & 0.030 \\
euro & 0.815 & 0.002 \\
etrend & -0.019 & 0.063 \\
japan80 & 0.010 & 0.059 \\
japan81 & 0.022 & 0.059 \\
japan82 & 0.001 & 0.057 \\
japan83 & -0.008 & 0.053 \\
japan84 & -0.037 & 0.032 \\
dom80 & 0.026 & 0.032 \\
dom81 & 0.084 & 0.031 \\
dom82 & 0.126 & 0.030 \\
dom83 & 0.102 & 0.031 \\
dom84 & 0.064 &
\end{tabular}

The regression had 2217 observations and an $R^{2}$ of 0.80 . 
might provide a distorted picture of the effects of the VER. How distorted? The model predicts that Japan raised prices by about 16 percent per year due to the VER during the first few years of that policy. I am skeptical that this occurred. Using essentially the same aggregate data that the author had, I regressed the log of list prices on vehicle characteristics, time trends, and dummy variables for Japanese and domestic producers interacted with year dummies. The results are reported in Table 1 . Those results indicate that there was no significant increase in Japanese prices (conditional on trends and characteristics) due to the VER. Domestic producers, on the other hand, raised prices significantly. A reasonable hypothesis might be that the Japanese responded to the VER by moving up-market and by jumping the VER and producing in the U.S. Ignoring direct foreign investment is an important omission.

\section{NAFTA}

All of the above comments are, relative to the treatment of NAFTA, picky and should not overshadow the fact that the author's analysis is still heads above many existing studies. The treatment of NAFTA, it seems to me, is just plain incorrect and misleading. The analysis unnecessarily contributes to a perception that NAFTA will cost the U.S. automobile industry jobs. In the end, the author finds small effects due to NAFTA, but this for the wrong reasons.

NAFTA is modelled as a decrease in Japanese, German, and/or American marginal costs. The story underlying this is that under NAFTA, firms will move some operations to Mexico for exporting into the U.S. This argument is used vociferously by critics of NAFTA who argue that NAFTA will export jobs from the U.S. to Mexico. I am troubled by this modelling decision. Consider first the case of the Japanese firms. My understanding of the NAFTA (see Chapter 4, Article 403 of the December $1992 \mathrm{draft}$ ) is that it effectively prohibits Japanese firms from setting up operations in Mexico for export into the U.S. The sole exception is Nissan, as thcy have cxisting operations in Mexico. But as Nissan's market share in the U.S. has slipped, Nissan finds itself with substantial excess capacity in the U.S. and is not likely to move more operations to Mexico. The other (and larger) Japanese firms will be prohibited from engaging in exactly the sort of behavior that is modelled in the paper. European firms are small players. The largest in Mexico is Volkswagen and its production facilities are quite dated and unlikely to be the source of competitive exports into the U.S. The notion that U.S. firms will move to Mexico lowering marginal cost and then export back to the U.S. in response to NAFTA is also questionable. U.S. firms can produce in Mexico now if they wish, and they have more or less found that it 
only pays to produce very labor-intensive parts there. Given excess capacity in the U.S., a much more likely outcome of NAFTA is that U.S. firms will produce in the U.S. for export to the previously protected Mexican market.

Modelling NAFTA as a lowering of marginal cost seems more consistent with a general exchange rate depreciation for foreign producers. This may happen some time. (Although, right now the opposite is true.) In any case, it is not how NAFTA will affect the automobile industry.

\section{References}

Berry, S., 1993, Discrete choice models of oligopoly product differentiation, Rand Journal of Economics.

Goldberg, P., 1992, Product differentiation and oligopoly in international markets: The case of the U.S. automobile industry, mimeo. 